REVISTA de

PEDAGOGIE

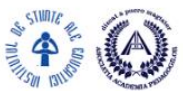

JOURNAL of

PEDAGOGY

http://revped.ise.ro

Print ISSN 0034-8678; Online ISSN: 2559 - 639X

\title{
TEACHERS' SELF-EFFICACY AND BURNOUT DURING ONLINE SCHOOL
}

AUTOEFICACITATEA ŞI BURNOUT-UL ÎN RÂNDUL PROFESORILOR, ÎN PERIOADA ŞCOLII ONLINE

\section{Adela Mihaela ŢĂRANU, lleana VĂTĂŞESCU, Bianca VĂTĂŞESCU}

\author{
Journal of Pedagogy, 2021 (2), 59 - 78 \\ https://doi.org/10.26755/RevPed/2021.2/59
}

The online version of this article can be found at: https://revped.ise.ro/en/rp-2021-2/

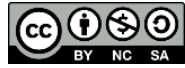

This work is licensed under the Creative Commons Attribution-NonCommercial-ShareAlike 4.0 International License. To view a copy of this license, visit http://creativecommons.org/licenses/by-nc-sa/4.0/ or send a letter to Creative Commons, PO Box 1866, Mountain View, CA 94042, USA.

Published by:

Centrul Național de Politici și Evaluare în Educație

UNitATEA DE CERCETARE ÎN EDUCAȚIE

https://www.ise.ro/

https://rocnee.eu/

Further information about Revista de Pedagogie - Journal of Pedagogy can be found at:

Editorial Policy: http://revped.ise.ro/editorial-policy/

Author Guidelines: http://revped.ise.ro/en/author-guidelines/ 


\title{
AUTOEFICACITATEA ŞI BURNOUT-UL ÎN RÂNDUL PROFESORILOR, ÎN PERIOADA ŞCOLII ONLINE
}

\author{
Adela Mihaela ăranu* \\ Universitatea Tehnică de Construc ii Bucureşti, \\ Departamentul pentru Pregătirea Personalului Didactic, \\ Bucureşti, România \\ adela.taranu@ise.ro
}

Ileana Vătăşescu**

Cabinet Individual de Psihologie,

Craiova, România

iulia_cib@yahoo.com

Bianca Vătăşescu***

Cabinet Individual de Psihologie,

Craiova, România

vatasescu.bianca@gmail.com

\section{Rezumat}

În timpul pandemiei de COVID-19, trecerea la învă ământul online a schimbat substan ial caracteristicile activită ilor profesorilor, în special datorită folosirii intensive a telecomunica iilor. O serie de studii recente explorează deja efectele produse de aceste schimbări de cadru asupra comportamentului individual şi atrag aten ia asupra riscurilor în zona sănătă ii mintale pentru cei implica i. Date anterioare indică faptul că nivelul de burnout resim it de profesori este mai puternic decât cel al persoanelor cu alte profesii (Shoji et al., 2016), însă studiile care explorează stresul şi burnout-ul asociate cu munca online sunt incipiente.

Studiul de fa ă analizează rela ia dintre burnout şi autoeficacitate pentru un lot de 50 de

* Conferen iar universitar doctor, Departamentul pentru Pregătirea Personalului

Didactic, Universitatea Tehnică de Construc ii Bucureşti, Bucureşti, România.

Cercetător ştiin ific gr. II - Centrul Na ional pentru Politici şi Evaluare în

Educa ie - Unitatea de Cercetare în Educa ie, București, România.

** Psihoterapeut, Cabinet Individual de Psihologie, Craiova, România.

*** Psiholog clinician, Cabinet Individual de Psihologie, Craiova, România. 
profesori dintr-o şcoală în care s-a trecut la predarea online. Necesitatea cercetării acestei asocieri pleacă de la premisa că eficacitatea autopercepută este importantă în mobilizarea profesorului pentru schimbările aşteptate în perioada predării online. Diferite studii indică o corela ie inversă între autoeficacitate şi burnout (Friedman, 2003), respectiv între autoeficacitatea profesorului şi două fa ete ale burnout-ului: epuizare emo ională şi depersonalizare (Skaalvik \& Skaalvik, 2010). Ne-am propus explorarea asocierii de moment între variabilele dependente măsurate şi estimarea factorilor care au avut impact negativ asupra autoeficacită ii percepute a profesorilor în perioada lucrului în online. Chiar dacă datele surprinse nu se pot generaliza şi nu se poate vorbi despre o rela ie cauză-efect, studiul de fa ă surprinde un moment real care poate fundamenta o interven ie de ameliorare/ optimizare, cel pu in la nivelul şcolii de referin ă.

Cuvinte-cheie: autoeficacitate, burnout-ul profesorilor, pandemia de COVID-19, predare online.

\section{Abstract}

During the COVID-19 pandemic, the transition to the online education substantially changed the characteristics of the teachers' activities, especially due to the intensive use of telecommunications. A number of recent studies are already exploring the effects of these framework changes on individual behavior and drawing attention to the risks of mental health for those involved. Previous data indicate that the level of burnout experienced between the teachers is much stronger compared to the symptoms felt by other professionals (Shoji et al., 2016), but studies exploring the stress and burnout associated with working online are incipient.

The present study analyzes the relationship between burnout and self-efficacy for a group of 50 teachers from a secondary school during online teaching. The need to research this correlation starts from the premise that self-perceived effectiveness is important in mobilizing the teachers for the expected changes during online teaching. Previous data indicate an inverse correlation between self-efficacy and burnout (Friedman, 2003), respectively between teachers self-efficacy and two facets of the burnout: emotional exhaustion and depersonalization (Skaalvik \& Skaalvik, 2010). Our aim is to explore the momentary correlation between the dependent variables and to estimate the factors that had a negative impact on the perceived self-efficacy of teachers during online work. Even if the captured data cannot be generalized and we cannot talk about a cause-effect relation, the present study captures a real moment that can substantiate an improvement/optimization of the intervention, at least at the level of the reference/referential school.

Keywords: COVID-19 pandemic, online teaching, teacher burnout, teacher selfefficacy. 


\section{Introducere}

În contextul măsurilor de distan are socială, educa ia s-a aflat în fa a unei provocări care a putut fi gestionată cu precădere cu suport digital. Pandemia de COVID-19 a avut un impact major asupra telecomunica iilor, iar studiile confirmă faptul că a crescut exponen ial utilizarea aplica iilor media care permit teleconferin ele, învă area online şi comunicarea socială pe re elele de socializare (Mheidly et al., 2020). Schimbarea rutinelor individuale şi institu ionale au adus provocări legate de starea de bine a personalului din învă ământ, a cursan ilor şi a părin ilor şi a afectat capacitatea şcolilor de a răspunde la aceste provocări şi de a oferi sprijin pentru elevi şi personal.

Potrivit OMS (2020), gestionarea stresului şi anxietă ii devine principala problemă de sănătate mintală generată de pandemia de COVID-19. Date de cercetare arată că persoanele care au petrecut mai mult de 10 zile în carantină/ lockdown erau mai predispuse să raporteze simptome de stres posttraumatic, confuzie şi furie, fa ă de perioada anterioară (Brooks et al., 2020). Se estimează că în perioada lockdown-ului din 2020, pe lângă factorii de stres genera i de izolarea în case, factorii asocia i cu telecomunica iile au accelerat inciden a burnout-ului (Mheidly et al., 2020). De asemenea, datele anterioare arată că nivelul de eficacitate al elevilor a fost scăzut în clasele unde profesorii au ob inut scoruri ridicate la nivelul de stres şi burnout şi redus la strategii de coping (Herman et al., 2018).

Studiul ETUCE (2021) privind aspecte ocupa ionale ale personalului din sistemele de învă ământ din 40 de tări europene, inclusiv România, avertizează alături de UNESCO asupra faptului că profesorii au experimentat niveluri mai mari de distres din cauza volumului de muncă în timpul şcolii la distan ă. Între nevoile profesorilor raportate de responden ii la studiu, suportul psihologic se află pe locul trei (după asigurarea unui mediu sigur şi sănătos de muncă şi sprijin financiar pentru tehnologie).

Referitor la con inutul muncii, responden ii profesori în cele mai ample studii din România în perioada şcolii la distan ă indică provocări, chiar obstacole în eficien a activită ii referitoare la accesul la echipamente şi internet de calitate necesare pentru desfăşurarea activită ilor online cu elevii, resurse de timp ample solicitate de pregătirea şi organizarea activită ilor online, insuficienta 
dezvoltare a competen elor digitale necesare pentru utilizarea diferitelor instrumente şi aplica ii online, disconfort profesional în interac iunea cu elevii în contexte online (Botnariuc et al., 2020; UCE-CNPEE, 2020). În acelaşi timp se consemnează în procente situate în jurul valorii de $40 \%$ stări precum confuzie, nerăbdare, teamă, furie, triste e, îngrijorare, nemul umire şi nervozitate resim ite în mare şi foarte mare măsură de profesori (ISMBCMBRAE, 2020).

\subsection{Burnout-ul în rândul profesorilor}

Burnout-ul este cunoscut sub numele de sindrom de epuizare cronică şi atitudine negativă fa ă de muncă, cu o etiologie legată de gestionarea defectuoasă a stresului în muncă. În timp, acest concept a primit mai multe defini ii şi diferite dimensiuni de bază, dar trei sunt cele mai răspândite astăzi - epuizare, cinism/ depersonalizare şi nivel scăzut de realizare personală/ ineficien ă (Bakker \& Sanz-Vergel, 2020). Epuizarea este descrisă ca un sentiment de pierdere a energiei, din cauza expunerii continue la condi ii de muncă extrem de solicitante; este simbolică şi cel mai strâns asociată cu performan a în rol, dar şi cu alte rezultate organiza ionale cum sunt absenteismul şi performan a autoraportată la locul de muncă (Schaufeli \& Buunk, 2003). Cinismul/ depersonalizarea este o stare de detaşare ostilă de munca proprie, înso ită de iritabilitate, atitudini inadecvate şi retragere; apare ca urmare a epuizării emo ionale şi este ini ial un mecanism defensiv, care ac ionează ca un tampon emo ional sub forma unei preocupări detaşate cu poten ial de transformare în dezumanizare (Maslach \& Leiter, 2016). Sentimentul de nerealizare este adesea asociat cu o productivitate scăzută şi incapacitatea de a face fa ă solicitărilor. Oamenii tind să-şi piardă progresiv credin a în capacitatea lor de a face la ceea ce li se cere, ceea ce poate duce la un verdict autoimpus de eşec (Maslach \& Leiter, 2016). Se estimează că experien a epuizării tinde să reducă încrederea pe care o au lucrătorii în îndeplinirea cu succes a sarcinilor lor (Bakker et al., 2003), conducând la o scădere a performan ei lor. În acelaşi timp, cinismul şi ineficien a din cadrul burnout-ului tind să afişeze modele mai pu in consistente în cadrul studiilor care măsoară performan a în muncă (Taris, 2006).

Metaanalizele care au lucrat cu datele ob inute în rândul cadrelor didactice 
au surprins un burnout mai puternic decât studiile efectuate în rândul lucrătorilor cu alte ocupa ii (Shoji et al., 2016).

În urma studiului în care Farber a estimat că aproximativ $20 \%$ dintre profesorii americani se confruntă cu burnout (1983), în baza experien ei psihoterapeutice acesta reconsideră abordarea conceptului ca sindrom cu etiologie şi simptome relativ consistente în cazul tuturor indivizilor şi propune trei profiluri de burnout (Farber, 2000): (1) burnout tip epuizare/ uzură, caz în care o persoană se dezangajează de muncă, sim indu-se depăşit în confruntarea cu stresul; (2) burnout clasic/frenetic, caz în care o persoană lucrează din ce în ce mai mult atunci când se confruntă cu factorii stresori, uneori riscându-şi sănătatea şi ignorându-şi via a personală; (3) tipul demotivat, în cazul persoanelor care se confruntă sau percep condi iile de muncă monotone şi nestimulative; pentru această categorie stresul muncii nu este deosebit de mare, dar recompensele nu sunt intrinseci şi în cele din urmă îşi pierd implicarea şi creativitatea profesională.

Potrivit lui Farber (2000), profilul profesorului predispus la burnout este: vârstă sub 40 de ani, predă în ciclul gimnazial sau liceal, idealişti sau pasiona i de munca lor, tind să fie influen a i de evenimente externe/ situa ii care scapă controlului mai degrabă decât de reac ii interne. Factorii de stres cel mai des experimenta i de către profesori sunt: muncă excesivă, clase numeroase şi elevi apatici şi/sau perturbatori. Tipul de şcoală care generează un mediu de lucru ce favorizează burnout-ul: şcoli urbane de mari dimensiuni, săli de clasă supraaglomerate, deteriorate sau murdare, personal şi echipamente insuficiente, management care nu oferă sprijin interpersonal sau administrativ pentru eforturile profesorilor. În cele din urmă, subevaluarea cronică a muncii profesorilor şi, în mod similar, continuarea denigrării muncii îndeplinite în primul rând de femei constituie un context social care îi fac pe profesori să se simtă neaprecia i şi să muncească sub presiunea de a ob ine rezultate educa ionale „mai bune” (Farber, 2000).

De-a lungul timpului au fost testate numeroase programe de interven ie pentru diminuarea burnout-ului în rândul profesorilor, cele mai comune componente ale acestor programe incluzând practicile de tip mindfulness, tehnicile de relaxare, cele de identificare şi corectare a gândurilor disfunc ionale/ negative şi sprijinul colegial (Ansley et al., 2021). Date recente de cercetare arată că aceste abordări sunt eficiente pentru epuizarea emo ională şi nerealizarea 
personală, însă eficacitatea acestor interven ii este aproape nulă în ceea ce priveşte depersonalizarea (Iancu et al., 2018).

\subsection{Autoeficacitatea profesorilor}

Constructul de autoeficacitate indică percep ia asupra propriei capacită ii de a îndeplini sarcini zilnice previzibile care, pe termen lung, modelează procesul de luare a deciziilor. Conceptul de autoeficacitate se bazează în principal pe două teorii psihologice influente ale secolului al XX-lea: locul controlului şi teoria social-cognitivă. În ceea ce priveşte locul controlului, autoeficacitatea profesorului este descrisă ca fiind convingerea lor că performan a elevilor poate fi modelată de profesor, dincolo de influen ele mediului de acasă (Vieluf et al., 2013). Bandura (2019) subliniază că percep ia privind eficacitatea personală determină modul în care persoana percepe oportunită ile şi obstacolele din mediu şi afectează alegerea ac iunilor, efortul şi timpul pe care aceştia sunt dispuşi să le investească când se confruntă cu dificultă i. Persoanele eficiente au mai multe şanse să-şi stabilească obiective mai provocatoare, tind să fie mai rezistente şi să experimenteze mai pu ine emo ii negative în procesul de atingere a acestor obiective (Bandura, 2019). Mai mult, autoeficacitatea corelează negativ cu epuizarea, sugerând că persoanele cu autoeficacitate generală scăzută au o stimă de sine scăzută şi cogni ii negative cu privire la realizările lor (Yao et al., 2018).

Autoeficacitatea profesorului (teacher self-efficacy) a fost descrisă ca un indicator subiectiv al măsurării modului în care profesorii pot realiza sarcini specifice în profesia didactică şi a fost unul dintre cele mai studiate constructe în formarea profesorilor (Morris et al., 2017). Ea este strâns legată nu numai de nivelul stării de bine în activitatea profesională, ci şi de rezultatele şcolare ale elevilor (Vieluf et al., 2013). Studii recente eviden iază faptul că profesorii cu un nivel raportat de autoeficitate ridicat sunt disponibili pentru o rela ie profesională autentică cu elevii şi experimentează mai multă satisfac ie profesională (Granziera \& Perera, 2019). De asemenea, fac apel la creativitate în sarcinile de predare pentru a-i determina pe elevi să în eleagă subiectele complexe sau dificile (Zee \& Koomen, 2016) şi sunt motiva i să diversifice strategiile prin utilizarea resurselor educa ionale digitale de învă are (Glackin \& Hohenstein, 2018). 
Potrivit studiilor recente, aceste asocieri dintre predarea la clasă şi autoeficacitate nu pot fi transferate în cazul predării online. Din raportările profesorilor, autoeficacitatea este percepută ca fiind mai redusă în contextul predării online comparativ cu predarea în mediul fizic (Johnson et al., 2020), mai ales în cazul profesorilor fără experien ă de predare online şi pentru cazurile în care grupurile de elevi au fost la fel de numeroase ca în cadrul fizic (Kenrick, 2020).

Un studiu recent care a măsurat autoeficacitatea în contextul predării online în diferite momente ale pandemiei de COVID-19 pentru 351 de profesori din China a concluzionat că autoeficacitatea în raport cu utilizarea tehnologiei a crescut în timp, odată cu acumularea de experien ă (Ma et al., 2021).

Printre factorii care au condus la scăderea autoeficacită ii asociate predării online, studiile consemnează dificultă ile anticipate cu utilizarea tehnologiei, diminuarea conexiunii socio-emo ionale cu elevii, dificultă ile de lucru cu elevii care prezintă un interes scăzut pentru disciplinele şcolare, cunoaşterea insuficientă a aspectelor pedagogice ale predării online şi caracteristicile consumatoare de timp ale predării online (Bao, 2020; Johnson et al., 2020; Ma et al., 2021; Putri et al., 2020; Scull et al., 2020).

Cercetările efectuate cu privire la stres arată că autoeficacitatea poate func iona ca o resursă - factor individual de autoreglare, ce poate fi activată pentru a minimiza efectele presiunii resim ite şi determină recuperarea după stresul resim it la locul de muncă (Shoji et al., 2016).

O serie de studii au investigat corela ia dintre burnout şi autoeficacitatea profesorului. Zee şi Koomen (2016) au analizat studii publicate între 1976 şi 2014 şi au observat faptul că asocierea dintre burnout şi autoeficacitatea variază de la -0,17 la -0,63 (mediana de -0,25). Mai mult, corela ia între autoeficacitatea profesorilor şi cele trei dimensiuni ale burnout-ului profesorului arată o corela ie între autoeficacitate şi epuizare ce variază de la -0,09 la -0,76 (mediană - 0,25), corela ie între autoeficacitate şi realizare personală ce variază de la 0,13 la 0,75 (mediană 0,36 ) şi corela ie între autoeficacitate şi depersonalizare ce variază de la -0,16 la -0,6 (mediană 0,33). O altă metaanaliză ce include 29 de studii înregistrează o corela ie medie de -0,33 între burnout şi autoeficacitate în rândul profesorilor (Shoji et al., 2016). 
$\mathrm{Cu}$ toate acestea, nu s-a găsit nicio corela ie semnificativă între nivelul autoeficacită ii profesorilor în online şi burnout (Ma et al., 2021). Acest lucru ar putea fi asociat cu faptul că profesorii devin mai pu in energici din cauza multitudinilor sarcinilor zilnice de predare, dar îşi men in autoeficacitatea ridicată raportându-se la realizările lor în predare într-un context diferit/ provocator (Dicke et al., 2018).

\section{Metodologia cercetării}

Studiile sus in existen a unui nivel crescut de burnout în rândul profesorilor. În contextul izolării, al incertitudinii specifice perioadei pandemiei de Covid-19, al schimbării practicilor de predare şi al utilizării intensive a suportului digital în educa ie, anticipăm un nivel scăzut de autoeficacitate şi un nivel crescut al burnout-ului profesorilor.

Metodologia de cercetare porneşte de la concluziile datelor anterioare, potrivit cărora autoeficacitatea este invers corelată cu burnout-ul raportat (Friedman, 2003), respectiv cu două fa ete ale burnout-ului: epuizare emo ională şi depersonalizare (Skaalvik \& Skaalvik, 2010).

De asemenea, s-a luat în considerare următorul aspect: chiar dacă un individ este autoeficace la anumite sarcini, nu înseamnă că este la fel de capabil în toate celelalte sarcini (Bandura, 2019). Am avut în vedere faptul că, în contextul pandemiei generate de Covid-19, autoeficacitatea profesorilor cu privire la modul de a-şi realiza sarcinile a fost un construct în continuă modificare, pe fondul noilor abilitări necesare, cu precădere în zona digitalizării; de aceea, studiul de fa ă s-a raportat la activitatea profesorilor după aproximativ şase luni de la debutul activită ii didactice online.

\subsection{Obiective}

Acest studiu investighează asocierea dintre autoeficacitatea percepută şi burnout-ul în rândul profesorilor dintr-o şcoală gimnazială, raportate la ultimele şase luni de activitate didactică online. Ne-am propus explorarea asocierii de moment între variabilele măsurate şi estimarea factorilor individuali şi 
contextuali care au avut impact negativ asupra autoeficacită ii percepute a profesorilor în perioada predării online.

\subsection{Participan i şi procedură}

Popula ia investigată a fost formată din profesori califica i care predau la ciclul primar şi gimnazial într-o şcoală din mediul urban. Criteriile de includere în lot au vizat vârsta între 22 şi 55 de ani şi experien ă minimă de 3 ani în învă ământ, pentru a nu aduce factori suplimentari cu poten ial în afectarea nivelului de autoeficacitate percepută (poten ial deficit ridicat în zona competen elor didactice sau digitale). A rezultat un lot de 50 profesori, relativ omogen la criteriul gen, $60 \%$ dintre aceştia cu o experien ă de predare în învă ământul preuniversitar între 10 şi 20 de ani şi vârsta între 30 şi 45 de ani, $100 \%$ fără experien a predării online (din rol de profesor/ instructor sau de cursant). Participarea persoanelor la studiu a fost voluntară şi în baza consim ământului informat al responden ilor în toate etapele.

Colectarea datelor s-a realizat online în perioada ianuarie-martie 2021, prin autoraportare în prima etapă şi interviuri individuale online în a doua etapă a studiului. Participan ilor li s-a comunicat necesitatea raportării într-un spa iu privat, lipsit de zgomote şi fără întreruperi, în două serii de aproximativ 15 minute pentru fiecare chestionar şi o serie de 60 minute (pentru interviu).

Studiul de fa ă nu are preten ii de generalizare a datelor surprinse şi nici de interpretări a acestora în termeni de cauză-efect, limitele principale fiind date de caracteristicile lotului de participan i redus numeric, relativ omogen structural şi fără varia ie în privin a institu iei/ mediului de provenien ă. Procedura utilizată surprinde însă un moment real cu caracteristici de noutate la nivel personal şi organiza ional, care poate fundamenta o interven ie de ameliorare/ optimizare, cel pu in la nivelul şcolii de referin ă.

\subsection{Metoda şi instrumentele utilizate}

Au fost colectate date cantitative cu două instrumente pentru măsurarea autoeficacită ii şi a burnout-ului, respectiv Scala de Auto-Eficacitate Independen ă [In] şi Inventarul Maslach de Măsurare a Burnout-ului. Date 
calitative referitoare la factorii asocia i autoeficacită ii au fost colectate prin intermediul interviurilor individuale semistructurate.

Scala de Auto-Eficacitate [In] face parte din Scalele IPIP (International Personality Item Pool) adaptate pe popula ia României, având un indice de fidelitate de .72 şi interval de încredere de .65-.76 (Iliescu et al., 2015). Cuprinde 10 itemi şi scala de scorare este de tip Likert in 5 trepte. Chestionarul a fost completat de întreaga popula ie a lotului (50 persoane).

Inventarul Maslach de măsurare a burnout-ului utilizează trei subscale pentru măsurarea celor trei dimensiuni ale burnout-ului - epuizarea emo ională, depersonalizarea şi sentimentul nerealizării personale; cuprinde 16 itemi, scorare pe scală de rating a frecven ei în 7 trepte (niciodată - zilnic). Pentru a evita sensibilizarea scalei, respoden ii nu au fost informa i referitor la faptul că itemii măsoară nivelul de burnout. Chestionarul a fost completat de întreaga popula ie a lotului (50 persoane).

Interviul individual de profunzime a fost utilizat pentru colectarea datelor calitative referitoare la factorii interni şi externi/ contextuali cu impact negativ asupra autoeficacită ii percepute cu privire la ultimele şase luni în care au predat online. Interviurile au fost organizate pentru şase profesori - trei din aceştia cu scor ridicat la autoeficacitate şi scăzut la burnout, trei cu scor scăzut la autoeficacitate şi crescut la burnout. Am optat pentru un interviu semistructurat condus de moderatori cu experien ă în domeniul psihologiei clinice, datorită tematicii specific clinice (legată de burnout) şi cu miză ridicată din punct de vedere psihologic şi social.

\section{Rezultate}

Pentru stabilirea corela iilor dintre autoeficacitate şi burnout, cu cele trei aspecte componente (respectiv epuizare, cinism/ depersonalizare şi nerealizare/ ineficien ă profesională), s-a calculat coeficientul Pearson. Au fost ob inute corela ii puternice între scale pentru popula ia de 50 de profesori care predau la ciclul primar şi gimnazial într-o şcoală din mediul urban. Se pot vedea în continuare tablourile corela iilor ob inute. 
Graficul nr. 1. Corela ii autoeficacitate - epuizare

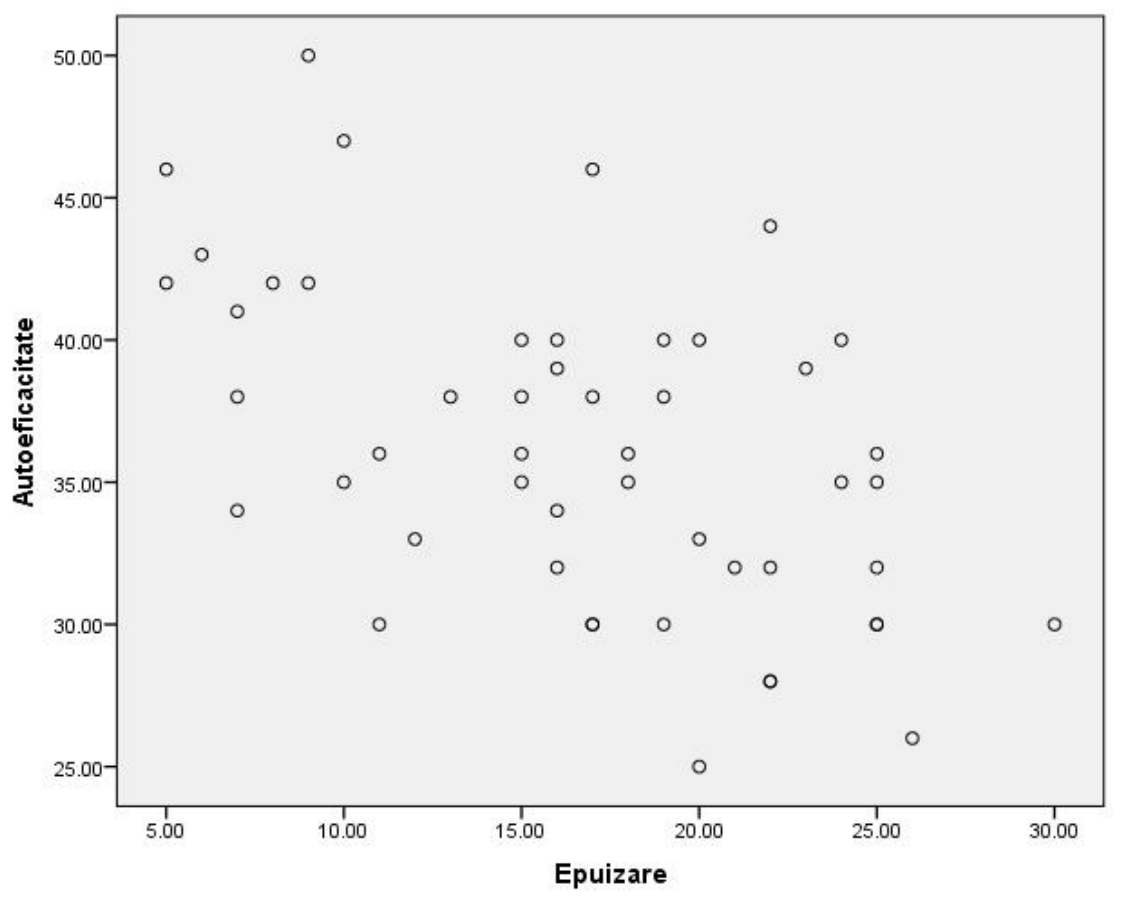

Pentru asocierea dintre autoeficacitate şi epuizare rezultatele studiului arată o corela ie negativă r=-.529 (p<0,005).

În ceea ce priveşte asocierea dintre autoeficacitate şi nerealizare/ ineficien ă profesională, rezultatele studiului arată o corela ie negativă r= -.499 $(p<0,005)$. Se observă ca sentimentul de nerealizare înregistrează cele mai crescute valori dintre cele trei dimensiuni ale burnout-ului. 
Graficul nr. 2. Corela ii autoeficacitate - nerealizarel ineficien ă profesională

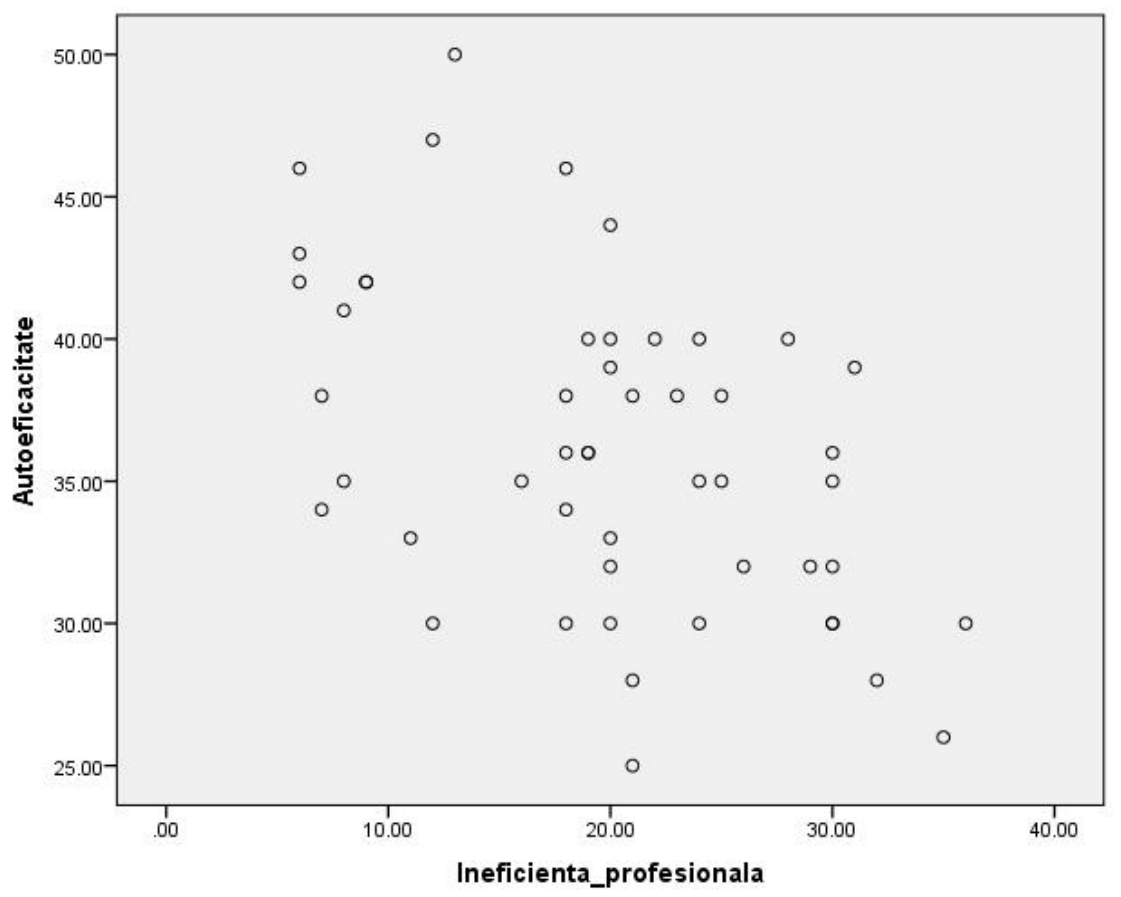

Similar, rezultatele studiului arată o corela ie negativă r=-.481 (p<0,005) pentru asocierea dintre autoeficacitate şi depersonalizare/ cinism. 
Graficul nr. 3. Corela ii autoeficacitate - cinism/ depersonalizare

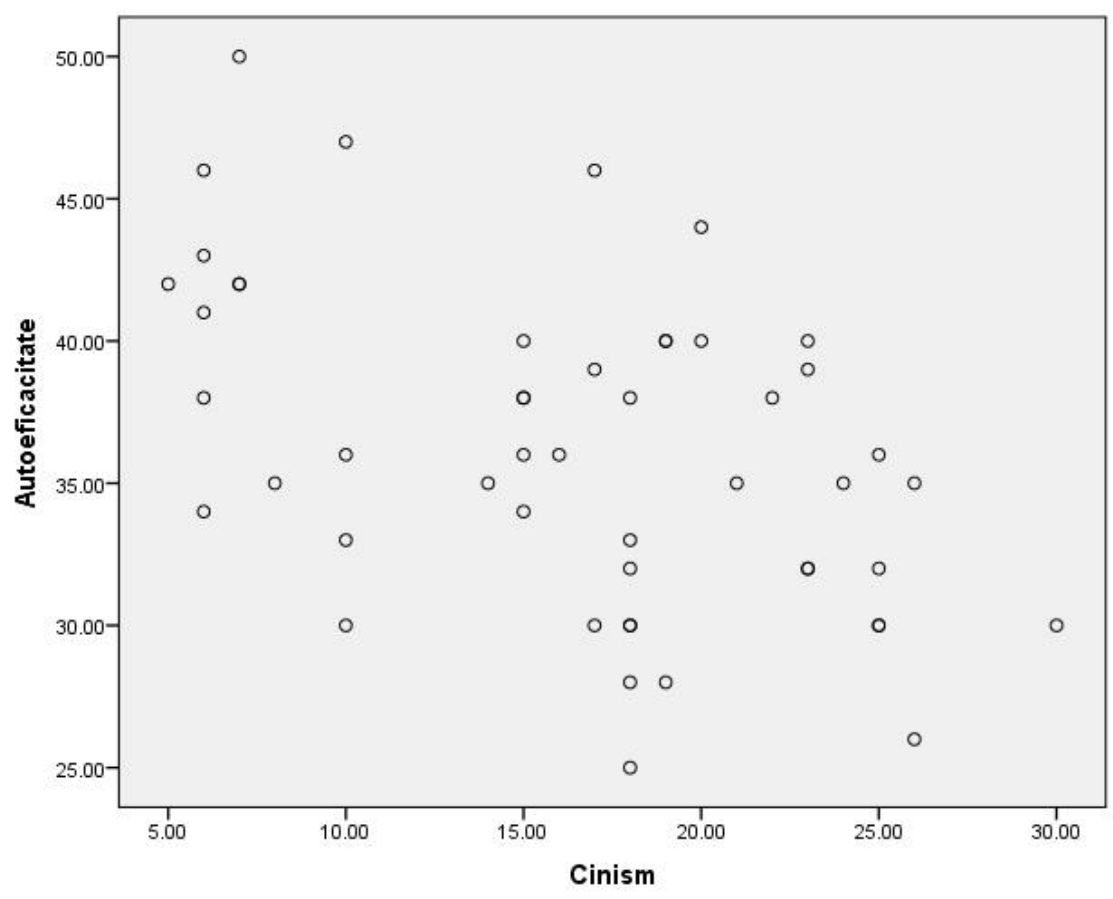

Pentru toate cele trei perechi de aspecte măsurate, rezultatele înregistrează corela ii negative (niveluri ridicate de epuizare, cinism/ depersonalizare şi nerealizare/ ineficien ă profesională se corelează cu un nivel scăzut de autoeficacitate), coeficientul indicând o mărime a efectului semnificativă. $\mathrm{Cu}$ toate acestea, analiza graficelor de tip scatterplot eviden iază că datele ob inute nu sunt suficient de bine grupate pentru a aduce informa ii suplimentare în confirmarea corela iilor puternice ob inute. O posibilă explica ie pentru această dispersie a datelor este lotul restrâns de cercetare şi varietatea caracteristicilor acestora - vârste diferite, cadru diferit de predare (primar/ gimnazial), nivel variabil de experien ă didactică, nivel variat al competen elor digitale. De asemenea, numărul de responden i nu a fost suficient de mare pentru a analiza modul în care autoeficacitatea şi burnoutul sunt modelate în func ie de numărul de elevi la clasă (sub 25 elevi şi peste 25 elevi) sau în func ie de durata de predare online şi numărul orelor de muncă pe zi. 
Ulterior, datele calitative colectate pentru identificarea factorilor individuali şi contextuali care au avut impact negativ asupra autoeficacită ii percepute a profesorilor în perioada predării online au permis creionarea unor profiluri relativ consistente.

Interviurile de profunzime realizate cu trei profesori care au ob inut cele mai scăzute rezultate în ce priveşte autoeficacitatea şi ridicate în privin a burnoutului resim it în ultimele şase luni de predare online au eviden iat următoarele caracteristici ale acestora: predau mai degrabă la gimnaziu, deci lucrează cu număr mare de elevi din clase diferite; profesori nou veni i în şcoală (sub 2 ani) sau slab integra i în comunitatea şcolii; resimt o presiune subiectivă crescută pentru succes profesional; resimt insatisfac ie în privin a recunoaşterii muncii de către elevi şi părin i; au sentimentul că nu au acces complet la informa ii dinspre managementul şcolii sau de la colegi; capacitate redusă de a identifica persoanele resursă sau de sprijin dintre colegi/ părin i/ elevi; nevoie resim ită de a fi în contact permanent cu informa ii din afară, asociată cu insecuritate; confruntarea cu evenimente dificile în plan personal; disconfort în rela ia cu tehnologia; toleran ă scăzută la disfunc iile tehnice întâmpinate; rutină slab instalată în plan personal şi profesional în perioada distan ării fizice determinate de pandemia de Covid-19; absen a încrederii că experien a acumulată în predarea online va putea fi valorificată profesional ulterior.

Interviurile de profunzime realizate cu trei profesori care au ob inut cele mai crescute rezultate în ce priveşte autoeficacitatea şi scăzute în privin a burnoutului resim it în ultimele 6 luni de activitate online au eviden iat următoarele caracteristici ale acestora: predau mai degrabă la ciclul primar, deci lucrează cu o singură clasă de elevi sau îşi cunosc bine majoritatea elevilor din perioada predării fa ă în fa ă; au conexiuni bune în comunitatea şcolii, se simt parte a acesteia; simt că munca lor este recunoscută de colegi şi de o parte dintre părin i; sunt relativ autonomi profesional; au un rol profesional bine conturat, îşi cunosc poten ialul şi limitele; caută şi identifică relativ uşor solu ii la dificultă i pe care le consideră provocări; sunt interesa i de educa ia digitală; au experien ă în lucrul pe proiecte; şi-au stabilit o rutina zilnică minimă pentru nevoi personale; au încredere că experien a acumulată în predarea online le aduce deja beneficii şi că o vor valorifica în viitor. 
Ambele tipuri de profesori au men ionat o serie de factori contextuali mai largi sau situa ionali care au poten at preocupările/ distresul asociat predării online. Între acestea, cele mai frecvent invocate dificultă i au vizat: lipsa de previzibilitate legată de durata activită ii online şi aşteptarea continuă ca aceasta să înceteze; îndrumări, decizii şi aşteptări neclare şi în schimbare venite din sistem pe linie ierarhică; creşterea cerin elor de tip birocratic în termene limită nerealiste; îngrijorări legate de modul de evaluare şi recunoaştere a muncii; practica într-o şcoală competitivă, cu presiune mare generată de părin i pentru performan ă; gestionarea lucrului cu elevi neuroatipici sau cu elevi perturbatori; scăderea timpul alocat vie ii de familie şi a calită ii acestuia; timpul prelungit pe device-uri alocat convorbirilor telefonice, mesageriei scrise şi emailurilor; gestionarea predării în scenariul hibrid (simultan online şi fizic la aceeaşi clasă de elevi).

\section{Concluzii}

Obiectivele prezentului studiu au vizat analiza rolului pe care autoeficacitatea îl are în rela ie cu burnout-ul resim it, în cazul unui lot de profesori care predau în şcoală gimnazială centrală într-un oraş de mari dimensiuni din România şi estimarea factorilor individuali şi contextuali care pot influen a scorurile ob inute.

Rezultatele studiului arată o asociere negativă puternică între autoeficacitate şi toate cele trei dimensiuni ale burnout-ului pe lotul evaluat, iar pe componenta sentiment de nerealizare/ lipsa eficien ei s-au înregistrat valorile cele mai ridicate ale burnout-ului profesorilor. Corela iile mari ob inute în cadrul cercetării de fa ă, raportate la perioada de predare online, sunt similare cu cele ale altor studii: cu cât este mai mic sentimentul de autoeficacitate perceput, cu atât este mai mare nivelul de burnout raportat (Friedman, 2003). In ceea ce priveşte profesorii, studiile care au vizat anterior activitatea fa ă în fa ă au consemnat corela ii puternice în special pentru două fa ete ale burnout-ului - epuizare emo ională şi depersonalizare (Skaalvik \& Skaalvik, 2010). Un studiu care a monitorizat periodic profesori din China în timpul pandemiei de COVID-19 timp de şase luni consemnează creşterea treptată a autoeficacită ii în contextul predării online, iar în ceea ce priveşte burnoutul, epuizarea a fost singurul moderator semnificativ raportat la autoeficacitatea 
profesorilor în predarea online (Ma et al., 2021). Pe de altă parte, Putri şi colab. (2020) au raportat faptul că profesorii nu percep cu încredere predarea online şi nu se consideră suficient de pregăti i pentru acest tip de predare.

Raportat la aceste date şi luând în considerare informa iile oferite de interviurile realizate, rezultatele acestui studiu pot fi atribuite, pe de o parte, aspectelor legate de neîncrederea în învă ământul online, de formarea deficitară a profesorilor în zona competen elor digitale şi a gestionării situa iilor noi/ de criză, iar pe de altă parte, pot fi atribuite aspectelor culturale şi organizatorice de tipul dependen ei profesorilor de decizii ierarhice şi de instabilitate structurală a sistemului educa ional, care generează insecuritate suplimentară celei generate de pandemie.

Deşi corela iile negative dintre autoeficacitate şi bournout, ob inute în cadrul studiului de fa ă, sunt semnificative, datele de cercetare trebuie analizate cu precau ie, având în vedere distribuirea neomogenă pe scatterplot determinată în primul rând de numărul mic de responden i. Diferite studii semnalează că nivelul de autoeficacitate şi nivelul de burnout pot fi influen ate de vârstă, gen, numărul de elevi la clasă, timpul de predare în online pe zi, durată de predare online (număr de luni) pe perioada distan ării fizice impuse de măsurile pentru combaterea pandemiei de Covid-19. Din cauza numărului redus de responden i şi caracterului relativ omogen al grupului, studiul de fa ă nu a putut verifica în ce măsură aceste variabile pot influen a nivelul de autoeficacitate şi burnout. Studiile viitoare pe popula ie mai numeroasă ar putea aduce date importante legate de impactul acestor variabile.

Datele ob inute în urma interviurilor de profunzime au semnalat, asemenea altor studii realizate în perioada pandemiei şi şcolii la distan ă (Botnariuc et al., 2020; ETUCE, 2021; ISMB-CMBRAE, 2020; UCE-CNPEE, 2020), nevoi ale profesorilor de ghidaj şi suport în primul rând de natură psihologică (pentru sine şi pentru a putea sprijini elevii), apoi tehnică şi metodologică/ didactică pentru a putea sus ine un construct puternic de autoeficacitate. Datele calitative arată că profesorii care au parcurs perioada predării online cu costuri şi riscuri mai mici din punct de vedere personal şi profesional au fost cei care au lucrat într-un context rela ional mai stabil şi colaborativ (elevi pe care-i cunoşteau bine, colaborare cu colegii şi părin ii) şi care au manifestat autonomie în plan profesional. Credem că, alături de dezvoltarea competen elor profesionale în 
contextul digitalizării educa iei, programele de dezvoltare personală şi a grupurilor/ echipelor de profesori ar putea răspunde nevoilor şi accentelor psihologice individuale şi organiza ionale semnalate de rezultatele acestor studii.

\section{Referin e}

- Ansley, B.M., Houchins, D.E., Varjas, K., Roach, A., Patterson, D., \& Hendrick, R. (2021). The impact of an online stress intervention on burnout and teacher efficacy. Teaching and Teacher Education, 98. https://doi.org/10.1016/j.tate.2020.103251

- Bakker, A.B., \& Sanz-Vergel, A.I. (2020). Burnout. In B.J. Carducci \& C.S. Nave (Eds.), The Wiley Encyclopedia of Personality and Individual Differences: Clinical, Applied, and Cross-Cultural Research: Vol. IV (1st ed., pp. 411-415). John Wiley \& Sons Ltd.

- Bakker, A.B., Demerouti, E., Taris, T.W., Schaufeli, W.B., \& Schreurs, P.J.G. (2003). A multigroup analysis of the job demands-resources model in four home care organizations. International Journal of Stress Management, 10(1), 16-38. https://doi.org/10.1037/1072-5245.10.1.16

- Bandura, A. (2019). Applying theory for human betterment. Perspectives on Psychological Science, 14(1), 12-15. https://doi.org/10.1177/1745691618815165

- Bao, W. (2020). COVID -19 and online teaching in higher education: A case study of Peking University. Human Behavior and Emerging Technologies, 2(2), 113-115. https://doi.org/10.1002/hbe2.191

- Botnariuc, P., Cucoş, C., Glava, C., Iancu, D., Ilie, M., Istrate, O., Labăr, A.V., Pânişoară, I.O., Ştefănescu, D., \& Velea, S. (2020). Şcoala online. Elemente pentru inovarea educa iei. Editura Universită ii din Bucureşti.

- Brooks, S.K., Webster, R.K., Smith, L.E., Woodland, L., Wessely, S., Greenberg, N., \& Rubin, G.J. (2020). The psychological impact of quarantine and how to reduce it: rapid review of the evidence. Lancet, 395(10227), 912-920. https://doi.org/10.1016/S0140-6736(20)30460-8

- Kenrick, A. (2020). Teacher perceptions of efficacy in the secondary virtual classroom: A phenomenological study. City University of Seattle.

- Dicke, T., Stebner, F., Linninger, C., Kunter, M., \& Leutner, D. (2018). Alongitudinal study of teachers' occupational well-being: Applying the job demands-resources model. Journal of Occupational Health Psychology, 23(2), 262-277. https://doi.org/10.1037/ocp0000070

- ETUCE. (2021). Occupational health and safety of teachers, academics and other education personnel in times of COVID-19. https://www.csee-etuce.org/ en/policy-issues/covid-19/4326-new-study-on-vaccination-of-teachers-by-etuce 
- Farber, B.A. (2000). Treatment strategies for different types of teacher burnout. Journal of Clinical psychology, 56(5), 675-689.

https://doi.org/10.1002/(SICI)1097-4679(200005)56:5<675::AID-JCLP8>3.0.CO;2-D

- Farber, B.A. (Ed.). (1983). Stress and burnout in the human service professions. Pergamon.

- Friedman, I.A. (2003). Self-Efficacy and Burnout in Teaching: The Importance of Interpersonal-Relations Efficacy. Social Psychology of Education, 6, 191-215. https://doi.org/10.1023/A:1024723124467

- Glackin, M., \& Hohenstein, J. (2018). Teachers' self-efficacy: Progressing qualitative analysis. International Journal of Research and Method in Education, 41(3), 271-290. https://doi.org/10.1080/1743727X.2017.1295940

- Granziera, H., \& Perera, H. (2019). Relations among teachers' self-efficacy beliefs, engagement, and work satisfaction: A social cognitive view. Contemporary Educational Psychology, 58, 75-84. https://doi.org/10.1016/j.cedpsych.2019.02.003

- Herman, K.C., Hickmon-Rosa, J.E., \& Reinke, W.M. (2018). Empirically derived profiles of teacher stress, burnout, self-efficacy and coping and associated student outcomes. Journal of Positive Behavior Interventions, 20(2), 90-100. https://doi.org/10.1177/1098300717732066

- Iancu, A.E., Rusu, A., Măroiu, C., Păcurar, R., \& Maricu oiu, L.P. (2018). The effectiveness of interventions aimed at reducing teacher burnout: A metaanalysis. Educational Psychology Review, 30(2), 373-396. https://doi.org/10.1007/s10648-017-9420-8

- Iliescu, D., Popa, M., \& Dimache, R. (2015). Adaptarea românească a Setului Interna ional de Itemi de Personalitate: IPIP-Ro. Psihologia Resurselor Umane, 13(1), 83-112.

- ISMB-CMBRAE. (2020). Studiu privind percep ia elevilor, părin ilor şi a profesorilor asupra activită ilor zilnice în perioada de autoizolare.

http://www.cmbrae.ro/2017/wp-content/uploads/2020/06/Raport_studiu_ ISMB_CMBRAE_context_pandemie_2020-1.pdf

- Johnson, N., Veletsianos, G., \& Seaman, J. (2020). U.S. faculty and administrators' experiences and approaches in the early weeks of the COVID-19 pandemic. Online Learning Journal, 24(2), 6-21. http://dx.doi.org/10.24059/olj.v24i2.2285

- Ma, K., Chutiyami, M., Zhang, Y., \& Nicoll, S. (2021). Online teaching selfefficacy during COVID-19: Changes, its associated factors and moderators. Education and information technologies, 26, 6675-6697. https://doi.org/10.1007/s10639-021-10486-3

- Maslach, C., \& Leiter, M.P. (2016). Understanding the burnout experience: recent research and its implications for psychiatry. World psychiatry, 15(2), 103111. https://doi.org/10.1002/wps.20311 
- Mheidly, N., Fares, M.Y., \& Fares, J. (2020). Coping with stress and burnout associated with telecommunication and online learning. Frontiers in Public Health, 8, 1-7. https://doi.org/10.3389/fpubh.2020.574969

- Morris, D., Usher, E., \& Chen, J. (2017). Reconceptualizing the sources of teaching self-efficacy: A critical review of emerging literature. Educational Psychology Review, 29, 795-833. https://doi.org/10.1007/s10648-016-9378-y

- OMS (2021, August 28). Mental health and psychological resilience during the COVID-19 pandemic. http://www.euro.who.int/en/health-topics/healthemergencies/coronavirus-covid-19/news/news/2020/3/mental-health-andpsychological-resilience-during-the-covid-19-pandemic

- Putri, R.S., Purwanto, A., Pramono, R., Asbari, M., Wijayanti, L.M., \& Hyun, C.C. (2020). Impact of the COVID-19 pandemic on online home learning: An explorative study of primary schools in Indonesia. International Journal of Advanced Science and Technology, 29(5), 4809-4818.

- Schaufeli, W.B., \& Buunk, B.P. (2003). Burnout: An overview of 25 years of research and theorizing. In M.J. Schabracq, J.A.M. Winnubst \& C.L. Cooper (Eds.), The handbook of work and health psychology (pp. 282-424). Wiley Online Library. https://doi.org/10.1002/0470013400.ch19

- Scull, J., Phillips, M., Sharma, U., \& Garnier, K. (2020). Innovations in teacher education at the time of COVID19: An Australian perspective. Journal of Education for Teaching, 46(4), 497-506. https://doi.org/10.1080/02607476.2020.1802701

- Shoji, K., Cieslak, R., Smoktunowicz, E., Rogala, A., Benight, C.C., \& Luszczynska, A. (2016). Associations between job burnout and self-efficacy: A meta-analysis. Anxiety, Stress and Coping, 29(4), 367-386.

https://doi.org/10.1080/10615806.2015.1058369

- Skaalvik, E.M., \& Skaalvik, S. (2010). Teacher self-efficacy and teacher burnout: A study of relations. Teaching and teacher education, 26(4), 1059-1069. https://doi.org/10.1016/j.tate.2009.11.001

- Taris, T.W. (2006). Is there a relationship between burnout and objective performance? A critical review of 16 studies. Work \& Stress, 20(4), 316-334. https://doi.org/10.1080/02678370601065893

- UCE-CNPEE. (2020). Invă area la distan ă. Anchetă cu privire la activită ile educa ionale desfăşurate în România, în perioada suspendării cursurilor scolare fa ă în fa $\breve{a}$.

https://www.ise.ro/wp-content/uploads/2020/08/Invatarea-la-distanta_Raportde-cercetare_august-2020.pdf

- Vieluf, S., Kunter, M., \& Van de Vijver, F.J. (2013). Teacher self-efficacy in crossnational perspective. Teaching and Teacher Education, 35, 92-103.

https://doi.org/10.1016/j.tate.2013.05.006 
- Yao, Y., Zhao, S., Gao, X., An, Z., Wang, S., Li, H., \& Dong, Z. (2018). General selfefficacy modifies the effect of stress on burnout in nurses with different personality types. BMC Health Services Research, 18. https://doi.org/10.1186/s12913-018-3478-y

- Zee, M., \& Koomen, H.M.Y. (2016). Teacher self-efficacy and its effects on classroom processes, student academic adjustment, and teacher well-being: A synthesis of 40 years of research. Review of Educational Research, 86(4), 9811015. https://doi.org/10.3102/0034654315626801

The online version of this article can be found at: http://revped.ise.ro/category/2021-en/

\section{(CC) $B Y-N C-3 A$}

This work is licensed under the Creative Commons Attribution-NonCommercial-ShareAlike 4.0 International License.

To view a copy of this license, visit http://creativecommons.org/licenses/by-nc-sa/4.0/ or send a letter to Creative Commons,

PO Box 1866, Mountain View, CA 94042, USA.
Versiunea online a acestui articol poate fi găsită la: http://revped.ise.ro/category/2021-ro/

\section{(cc) B B-NC-sA}

Această lucrare este licen iată sub Creative Commons Attribution-NonCommercial-ShareAlike 4.0 International License.

Pentru a vedea o copie a acestei licen e, vizita $i$ http://creativecommons.org/licenses/by-nc-sa/4.0/ sau trimite i o scrisoare către Creative Commons, PO Box 1866, Mountain View, CA 94042, SUA. 